\title{
PENGGUNAAN METODE SETIA (FAITHFUL) DALAM MENERJEMAHKAN KARYA SASTRA BERUPA CERITA PENDEK
}

\author{
Muhammad Aprianto Budie Nugroho \\ Pendidikan Bahasa Inggris, Universitas Kuningan, Indonesia \\ Emai: muh.apriantobn@Gmail.com
}

\begin{abstract}
ABSTRAK
Tujuan dari penelitian ini adalah menemukan bagaimana mahasiswa menggunakan metode penerjemahan Setia ( Faithful) dalam menerjemahkan karya sastra berupa cerita pendek berjudul "Blunder" karya Anton Chekov dari bahasa Inggris ke dalam bahasa Indonesia. Di dalam penelitian ini penulis menggunakan metode penelitian deskriptif dalam mengumpulkan data dan menganalisis data yang didapat dari hasil terjemahan Inggris-Indonesia dari mahasiswa tingkat tiga. Penulis menggunakan teori-teori penerjemahan dari Newmark dalam menganalisa metode apa yang digunakan oleh para mahasiswa dan Baker untuk menganalisis kesetaraan dalam penerjemahan. Berdasarkan hasil analisa dari hasil penterjemahan yang di lakukan oleh mahasiswa bisa di ambil sebuah kesimpulan bahwa hampir semua mahasiswa menggunakan metode Faithful dalam menenerjemahkan cerita pendek tersebut. Metode penerjemahan Faithful sering digunakan oleh mahasiswa, karena mahasiswa mencoba menerjemahkan secara persis makna kontekstual dari bahasa sumber. Selain itu ditemukan kesetaraan dalam penerjemahan yang dilakukan oleh para mahasiswa yaitu persamaan gramatikal.
\end{abstract}

Kata kunci : Metode Penerjemahan, Karya sastra, cerita pendek, kesetaraan gramatikal

\section{PENDAHULUAN}

Penerjemahan adalah sebuah aktifitas ketika seseorang (penerjemahan) mentransfer makna dari teks bahasa sumber kedalam bahasa target secara akurat. Akurasi sangat dibutuhkan dalam proses penerjemahan sehingga menghasilkan sebuah penerjemahan yang baik. Catford (1960:20) didalam bukunya menyatakan bahwa mengganti sebuah materi teks dari sebuah bahasa ke dalam materi teks yang setara dalam aturan baku bahasa lain. Seorang penerjemah harus berhati-hati dalam setiap kata yang digunakan ketika menerjemahkan, karena akan berpengaruh dalam kesetaraan makna hasil penerjemahan dari bahasa sumber kedalam bahasa target.

Penelitian ini bertujuan bagaimana mahasiswa menggunakan metode penerjemahan Setia (Faithful) dalam menerjemahkan karya sastra berupa cerita 
pendek berjudul "Blunder" karya Anton Chekov. Terdapat beberapa metode penerjemahan didalam buku yang ditulis Newmark, metode-metode tersebut adalah: metode penerjemahan kata demi Kata (word-for-word), metode penerjemahan harfiah (literal), metode penerjemahan Setia (Faithful), metode penerjemahan semantik, metode penerjemahan Bebas (free), metode penerjemahan idiomatik, dan yang terakhir metode penerjemahan komunikatif. Dari hasil analisis penerjemahan yang dilakukan mahasiswa dalam menerjemahkan cerita pendek "Blunder" karya Anton Chekov dari bahasa Inggris kedalam bahasa Indonesia didominasi dengan penunjukan metode faithful.

Menurut Bell dalam bukunya (1991:6) teks dalam bentuk bahasa yang berbeda mempunyai tingkat kesetaraan yang berbeda-beda, baik dalam tingkat presentasi (dalam kesetaraan kontek, semantik dan lexis-gramatikal) dan tingkat yang berbeda (kata demi kata, frasa demi frasa, kalimat demi kalimat). Terdapat tujuan baru telah ditetapkan dalam konsep kesetaraan (gramatikal, tekstual, kesetaraan pragmatik dan yang lainnya) yang membuat kemunculan berpengaruh dalam bidang ini.

Newmark (1988: 46) menyatakan bahwa penerjemahan faithfull berupaya mereproduksi makna kontekstual secara tepat/persis dalam rangka bahasa yang orisinal dalam gramatikal bahasa sumber. Didalam penelitian ini selain mencari tahu bagaimana metode penerjemahan setia (faithful) digunakan, peneliti juga mencari tahu kesetaraan didalam penerjemahan yang dilakukan oleh para partisipan. Menurut Bell (1991:16) teks dalam berbagai bentuk bahasa dapat mencapai kesetaraan dalam tingkat yang berbeda (sebagian atau sepenuhnya), juga mengenai perberbedaan tingkat dalam bentuk presentasi (kesetaraan mengenai, semantik, gramatikal, leksikal, dll) dan perbedaan tingkatan (kata demi kata, frasa demi frasa, kalimat demi kalimat).

Dalam penelitian ini peneliti menggunakan cerita pendek berjudul "Blunder" karya Anton Chekov sebagai materi penerjemahan. Menurut Klarer (2004: 20) cerita pendek adalah salah satu bentuk karya prosa/fiksi, berbeda dengan novel, cerita pendek mempunyai keterbatasan dalam panjang ceritanya, harus lebih sugestif, ketika novel bereksperimen dengan berbagai perspektif narasi, cerita pendek lebih fokus pada satu sudut pandang terkait dengan salah satu pandangan dari figur atau narator.

\section{METODE PENELITIAN}

Penelitian ini menggunakan metode penelitian Kualitatif menurut Creswell (2012) bahwa penelitian Kualitatif adalah proses pengelompokan berdasarkan pemahaman tradisi metode penelitian tertentu yang mengekspolrasi masalah sosial atau kemanusiaan. Peneliti membangun sebuah gambaran komplek, holistik, 
menganalisis kata-kata, melaporkan gambaran detail informasi-informasi dan mengadakan penelitian dalam setting yang natural.

Yvone Darlington dan Dorothy Scott (2003: 3) juga menambahkan, penelitian Kualitatif adalah bagaimana peneliti membangun pertanyaan penelitian, bagaimana para peneliti melakukan tugasnya melalui berbagai hambatan berupa hambatan ethika maupun politik dalam bidangnya, secara sistematis mengumpulkan data yang sesuai, serta menganalisis secara kaku dan lalu disebarluaskan hasil temuan dan pengaruh-pengaruhnya dalam penelitian. Desain Deskriptif adalah penelitian dimana peneliti melakukan penelitian dengan menyampaikan penelitian melalui cara deskriptif. Penelitian deskriptif di desain agar peneliti bisa mendeskripsikan atau mempresentasikan gambaran dari sebuah fenomena yang sedang diteliti.

Dari deskripsi diatas, peneliti menyediakan detail dari sebuah kejadian, kondisi atau situasi, dan yang terakhir peneliti menarik sebuah kesimpulan berdasarkan data yang telah dianalisis. Dengan menggunakan desain penelitian deskriptif, peneliti berusaha mendeskripsikan fakta-fakta mengenai objek dari penelitiannya, yaitu penggunaan metode penerjemahan setia (faithful) oleh mahasiswa semester enam dari Prodi Pendidikan Bahasa Inggris, Fakultas Keguruan dan Ilmu Pendidikan, Universitas Kuningan. Di dalam penelitian ini peneliti engambil lima sukarelawan dari mahasiswa tingkat tiga semester enam, karena pada semester tersebut mahasiswa telah mendapatkan cukup pengetahuan mengenai dasar-dasar ilmu kesusastraan, dan telah diajarkan teori-teori dasar penerjemahan, dan berbagai ilmu pendukung lainnya seperti semantik, dan pragamatik.

\section{HASIL PENELITIAN DAN PEMBAHASAN}

Dari hasil analisis data-data dari hasil terjemahan yang dilakukan oleh mahasiswa dalam menerjemahkan karya sastra, berupa cerita pendek berjudul "Blunder" karya Anton Chekov. Bisa disimpulkan bahwa penerjemah atau para mahasiswa mayoritas menggunakan metode penerjemahan setia (Faithful). Peter Newmark dalam bukunya menjelaskan bahwa metode penerjemahan Setia (Faithful) adalah sebuah metode penerjemahan yang berusaha mereproduksi makna kontekstual secara tepat sesuai dengan makna dari bahasa sumber-nya, sesuai deng konstruksi dari struktur gramatikal dari bahasa sumber-nya, penerjemah berusaha menerjemahkan makna dari bahasa sumber untuk menerjemahkan maksud dari sipenulis.

Dalam penerjemahan cerita pendek berjudul "Blunder", penerjemah menggunakan beberapa metode penerjemahan, dan para penerjemah atau para mahasiswa dominan menggunakan metode penerjemahan setia (faithful). Hal 
tersebut bisa dilihat dari beberapa kalimat yang diterjemahkan oleh para mahasiswa, antara lain;

Bsu : And you write like a spider!

BT : Dan kau menulis seperti seekor laba-laba!

Contoh penerjemahan diatas diambil dari partisipan 1 yang bisa dijadikan bukti bahwa penerjemah/mahasiswa menggunakan metode penerjemahan setia. Penerjemah menerjemahkan Bahasa Sumber ke dalam Bahasa Target secara setia, penerjemah menerjemahkan kata "and" dengan "dan", "you" dengan "kau", "like" dengan "seperti", "a" dengan "seekor", serta "spider" dengan "laba-laba". Di dalam terjemahan tersebut partisipan 1 juga menggunakan metode penerjemahan setia menerjemahkan kalimat lain yaitu;

Bsu: And what a queer man you are!

BT: Dan sungguh betapa anehnya kau ini!

Contoh kalimat tersebut diambil dari hasil penerjemahan partisipan 1, dari hasil penerjemahan kalimat tersebut bisa menjadi bukti bahwa partisipan tersebut menggunakan metode penerjemahan setia (faithful). Partisipan 1 menggunakan metode penerjemahan setia (faithful) dalam menerjemahkan Bahasa Sumber ke dalam Bahasa Target, contohnya adalah ketika partisipan 1 menerjemahkan "what a queer" dengan "sungguh betapa anehnya", dan hal tersebut sesuai dengan cerita yang terdapat dalam cerita pendek tersebut. Selain partisipan 1, di dalam penelitian ini partisipan 2 juga menggunakan metode penerjemahan setia (faithful), hal tersebut bisa dilihat dari hasil terjemahan dibawah ini;

Bsu : You are not Nekrassov ..

BT : Kamu bukan Nekrassov

Contoh kalimat diatas adalah hasil terjemahan yang dilakukan oleh partisipan 2 . Dari contoh diatas bisa disimpulkan bahwa partisipan 2 menggunakan metode penerjemahan setia (faithful) dalam menerjemahkan Bahasa Sumber (Bsu) kedalam Bahasa Targe (BT). Penggunaan metode penerjemahan setia (faithful) bisa dilihat ketika partisipan 2 menerjemahkan "you" dengan "kamu", dan "are not" dengan "bukan". Maka dari hasil penerjemahan tersebut bisa disimpulkan bahwa partisipan 2 juga menggunakan metode penerjemahan setia (faithful).

$\mathrm{BSu}$ : Shchupkin's mouth fell open with amazement and alarm.

BT : Mulut Shchumpkin seperti terbuka dengan kekaguman dan alarm. 
Contoh kalimat diatas adalah hasil terjemahan oleh partisipan 2, dan dari hasil terjemahan tersebut bisa dilihat bahwa partisipan 2 menggunakan metode penerjemahan setia (faithful). Hal tersebut bisa dilihat dari partisipan 2 menerjemahkan "Schupkin's mouth fell open" dengan "mulut schupkin seperti terbuka", dan "with amazement and alarm" dengan "dengan kekaguman dan alarm". Selain sering digunakan oleh partisipan 2, dari hasil analisis penerjemahan yang dilakukan oleh partisipan 3 juga bisa disimpulkan bahwa partisipan 3 juga menggunakan metode penerjemahan setia (faithful). Hal tersebut bisa dilihat dari contoh dibawah ini;

$\mathrm{BSu} \quad$ : You are an idiot!

BT : Kamu adalah Seorang idiot!

Kalimat diatas adalah hasil terjemahan yang dilakukan oleh partisipan 3, dan dari hasil terjemahan tersebut bisa dilihat bahwa partisipan 3 menggunakan metode penerjemahan setia (faithful). Penggunaan metode penerjemahan setia (faithful) bisa dilihat dari bagaimana partisipan 3 menerjemahkan "you " dengan "kamu", "are" dengan "adalah, "an" dengan "seorang", dan "idiot" dengan "idiot". Selain dari hasil penerjemahan diatas, penggunaan metode penerjemahan setia oleh partisipan 3 bisa dilihat dari hasil penerjemahan partisipan 3 seperti dibawah ini;

$\mathrm{BSu}$ : It would draw a tear from a stone!

BT : Itu akan mengeluarkan air mata dari sebuah batu!

Dari contoh penerjemahan diatas bisa dilihat bahwa partisipan 3 menggunakan metode penerjemahan setia (faithful) dalam menerjemahkan cerita pendek. Hal tersebut bisa dilihat dengan bagaimana partisipan 3 menerjemahkan kalimat diatas dengan; "it" diterjemahkan dengan "itu", "would" dengan "akan", "draw" dengan "mengeluarkan" "tear" dengan "air mata", "from a stone" dengan dari sebuah batu. Selain digunakan oleh partisipan 3, metode penerjemahan setia (faithful) juga digunakan oleh partisipan 4 , hal tersebut bisa dilihat dengan hasil terjemahan dari partisipan 4 dibawah ini.

$\mathrm{BSu}$ : We'll catch him..

BT : Kita akan tangkap dia.

Dari hasil penerjemahan diatas bisa diambil kesimpulan bahwa metode penerjemahan setia (faithful) digunakan oleh partisipan 4 dalam menerjemahkan cerita pendek tersebut. Hal tersebut bisa dilihat dari bagaimana partisipan 4 
menerjemahkan "we'll" dengan "kami akan", dan "cacth him" dengan "tangkap dia". Selain contoh diatas, partisipan 4 juga menggunakan metode penerjemahan setia (faithful) dalam menerjemahkan kalimat lain seperti contoh dibawah ini;

$\mathrm{BSu}$ : You hit one on the head with a ruler

BT : Kamu pukul satu di kepala dengan sebuah mistar

Kalimat diatas adalah hasil penerjemahan yang dilakukan oleh partisipan 4. dari hasil penerjemahan diatas bisa dilihat bahwa partisipan 4 menggunakan metode penerjemahan setia (faithful). Hal tersebut bisa dilihat dengan bagaimana partisipan 4 menerjemahkan "you" dengan "kamu", "hit" dengan "pukul", "one" dengan "satu", "on the head" dengan "di kepala", "with a ruler" dengan "dengan sebuah mistar". Selain partisipan 4 yang menggunakan metode penerjemahan, partisipan 5 juga menggunakan metode penerjemahan setia (faithful).

$\mathrm{BSu} \quad$ : "And -- and I bless you, too,"

BT : "Dan - dan aku memberkati kamu juga."

Di dalam hasil penerjemahan yang dilakukan oleh partisipan 5 bisa dilihat bahwa partisipan 5 menggunakan metode penerjemahan setia (faithful). Hal tersebut bisa dilihat dari bagaimana partisipan 5 menerjemahkan "and" dengan "dan", "I bless you, too" dengan "aku memberkatimu juga". Dari penerjemahan diatas, maka bisa diambil sebuah kesimpulan bahwa partisipan 5 menggunakan metode penerjemahan setia (faithful). Di dalam hasil penerjemahan lain, partisipan 5 juga menggunakan metode penerjemahan setia (faithful).

BSu : "take down the ikon," Peplove whispered in fluster"

BT : "turunkan gambar suci itu" Peplove berbisik dengan kebingungan"

Di dalam hasil penerjemahan yang dilakukan oleh partisipan 5 bisa dilihat bahwa partisipan 5 menggunakan metode penerjemahan setia (faithful). Hal tersebut bisa dilihat dari bagaimana partisipan 5 menerjemahkan "take down the ikon" dengan "turunkan gambar suci itu", "Peplove whispered in a fluster" dengan "berbisik dengan bingung".

Didalam penelitian ini ditemukan kesetaraan dalam hasil penerjemahan yang dilakukan oleh para partisipan. Hal tersebut berkaitan dengan metode penerjemahan yang digunakan oleh para partisipan, yang dominan dengan penggunaan metode penerjemahan setia (faithful). Kesetaraan yang ditemukan dalam hasil penerjemahan para partisipan adalah kesetaraan gramatikal, hal tersebut bisa dilihat dalam contoh penerjemahan yang dilakukan oleh partispan 3; 
$\mathrm{BSu} \quad$ : It would draw a tear from a stone!

BT : Itu akan mengeluarkan air mata dari sebuah batu!

Dari contoh hasil penerjemahan diatas bisa dilihat kesetaraan gramatikal yang bisa dilihat bagaimana partisipan 3 menggunakan kata-kata dalam Bahasa Target (BT) yang mempunyai kesetaraan gramatikal Bahasa Sumber baik dari struktur kalimat dan fungsi dari kata yang membentuk kalimat tersebut sehingga bentuknya tidak jauh beda dengan Bahasa Sumber (BSu). Kesetaraan garamatikal tidak hanya ditemukan dalam hasil penerjemahan dari partisipan 3, tapi juga ditemukan pada hasil penerjemahan dari partisipan, 1, 2, 4 dan 5. Kesetaraan gramatikal terjadi karena penerjemah berusaha menerjemahkan Bahasa Target (BT) kedalam Bahasa Sumber (BSu) sesuai dengan makna bahasa target dan berusaha sedekat mungkin baik secara makna maupun seca gramatikal.

\section{SIMPULAN}

Dari hasil penerjemahan yang dilakukan oleh lima partisipan yang merupakan mahasiswa Prodi Pendidikan Bahasa Inggris, Fakultas Keguruan dan Ilmu Pendidikan, Universitas Kuningan, bisa diambil sebuah kesimpulan bahwa dalam menerjemahkan karya sastra yang berupa cerita pendek berjudul "Blunder" karya Anton Chekov para mahasiswa atau partisipan menggunakan metode penerjemahan Setia (faithful). Hal tersebut terjadi karena mahasiswa berusaha untuk menerjemahkan cerita pendek tersebut berusaha untuk mempertahankan makna yang berasal dari Bahasa Sumber (BSu) kedalam Bahasa Target (BT) hingga dalam struktur bahasa-nya tidak banyak perubahan baik dalam Bahasa Sumber maupun hasil terjemahannya dalam Bahasa Target.

Hal tersebut terjadi dikarenakan para mahasiswa tidak terbiasa dalam menerjemahkan teks-teks dalam bentuk karya satra, cenderung sering berlatih menerjemahkan teksbook sehingga para partisipan cenderung menggunakan metode penerjemahan Setia (faithful) dalam setiap terjemahan mereka. Diharapkan input dari penelitian ini dapat memberikan masukan kepada para dosen maupun mahasiswa untuk banyak memberikan materi teks dari berbagai jenis genre yang berbeda sehingga kemampuan penerjemahan akan meningkat, dan akan memberikan pengalaman yang berharga dalam menerjemahkan teks dari berbagai genre.

Penggunaan metode penerjemahan setia (faithful) berpengaruh kepada kesetaraan yang ada pada hasil penerjemahan, yaitu kesetaraan gramatikal.

Kesetaraan gramatikal terdapat dalam hasil penerjemahan yang dilakukan oleh partisipan 1,2,3,4, dan 5 disebabkan karena para penerjemahan atau para partsipan ketika menerjemahkan Bahasa Sumber (Bsu) ke dalam Bahasa Target 
(BT) berusaha untuk tidak merubah baik susunan kata maupun makna yang terdapat dari Bahasa Sumber (BSu) ke dalam Bahasa Target.

\section{DAFTAR PUSTAKA}

Bell, Roger T. (1991). Translation and Translating: Theory and Practice. London: Longman.

Catford, J. C. (1965). A Linguistic Theory of Translation. London: Oxford University Press.

Creswell, J.W. (2012). Education Research, Planning, Conducting and Evaluating Quantitative and Qualitative Research. 4th edition. Boston: Pearson

Darlington, Yvonne and Dorothy Scott. (2002). Qualitative Research in Practice.Newsouth Wales: Allen and Unwin.

Klarer, Mario. 1999. An Introduction to Literature Studies Second Edition. London: Routledge

Newmark, Peter. (1988). A Textbook of Tranlation. London: Prentice Hall. 